\title{
Relationship among local content policy, indigenous oil firms' participation and job creation in Nigeria: a theoretical concept
}

\begin{abstract}
The focus of this paper is to explain in more detail the theoretical concept of the relationship among local content policy, indigenous oil firmsôparticipation and job creation in Nigeriaôs oil and gas sector. Some corpus of studies has described the relationship between local content policy and entrepreneurship in Nigeria, many of which relied on theory of firm popularized by Dew, Velamuri and Venkataraman (2004). However, they provide little understanding about how such influence relate to job creation, which is a focal objective of the policy. In this paper, we argue that there exist a linear link between local content policy and indigenous oil firmsôparticipation. But if such interaction fails to relate to job creation, then, the focal objective of the policy on job creation, in ensuring for value-added to the Nigerian economy, may not achieved.
\end{abstract}

Keyword: Local content policy; Indigenous firms' participation; Job creation; Value-added 